\title{
Data Collection for Implementation of the Mechanistic- Empirical Pavement Design Guide (MEPDG) in Izmir, Turkey
}

\author{
Mohammad Razeq SHAKHAN ${ }^{1}$ \\ Ali TOPAL ${ }^{2}$ \\ Burak ŞENGÖZZ
}

\begin{abstract}
Developing countries like Turkey are trying to implement the Mechanistic-Empirical Pavement Design Guide (MEPDG). The implementation of this method requires comprehensive local data collection, evaluation, and, if necessary, a local calibration. The objective of this study is to prepare local data such as climate, traffic, and materials for evaluation and local calibration of MEPDG for Izmir City. For this purpose, the climate and traffic data were obtained, analysed, and converted to the MEPDG format. Besides, the bound and unbound pavement material properties were determined. Since some of the obtained local data like climate, vehicle classification, traffic growth factor, and axle load distribution cannot be directly used as design inputs, they were developed and converted to a suitable format to be used in the MEPDG. The output of this study can be used as design inputs for the evaluation and local calibration of the MEPDG in Izmir and serves as a guide for data preparation for other parts of the country.
\end{abstract}

Keywords: Climate, data collection, materials, mechanistic-empirical pavement design guide (MEPDG), traffic.

\section{INTRODUCTION}

The MEPDG is an advanced and the most sophisticated pavement analysis and design method that calculates pavement structure responses and predicts different pavement performances under the combination of traffic loading and environmental conditions taking

Note:

- This paper was received on November 26, 2019 and accepted for publication by the Editorial Board on May 23, 2020.

- Discussions on this paper will be accepted by January 31, 2022.

- https://dx.doi.org/10.18400/tekderg.651399

1 Dokuz Eylul University, The Graduate School of Natural and Applied Sciences, Izmir, Turkey raziqshakhan@yahoo.com - https://orcid.org/0000-0002-9756-7331

2 Dokuz Eylul University, Department of Civil Engineering, Izmir, Turkey - ali.topal@deu.edu.tr https://orcid.org/0000-0002-2601-1926

3 Dokuz Eylul University, Department of Civil Engineering, Izmir, Turkey - burak.sengoz@deu.edu.tr https://orcid.org/0000-0003-0684-4880 
into various material properties consideration. The MEPDG consists of two models: 1) Mechanistic Model calculating the pavement responses (stresses and strains) based on engineering mechanics law. 2) Empirical Model predicts pavement distresses (rutting, topdown, bottom-up, and thermal cracking as well as the International Roughness Index (IRI)) using transfer regression equations [1], [2]. The implementation of the MEPDG in other parts of the world would require verification, local calibration, and validation for local materials, conditions, and construction policies since the MEPDG was calibrated based on the Longterm Pavement Program (LTPP) database in the USA. To carry out such efforts, comprehensive local data (e.g., materials, traffic, climate, and pavement distresses) are required to be collected [3], [4], [5].

Several countries have tried to collect local design data, to conduct sensitivity analysis, and to carry out the local calibration so as to facilitate the implementation of the MEPDG. In Italy, the local data such as traffic (e.g., vehicle classification, truck distribution, and truck axle load distribution), materials properties, and climate data were collected and analysed to conduct the local calibration of the MEPDG [6]. Traffic and climate data were collected to facilitate the implementation of MEPDG in India [7]. The local data (e.g., traffic, climate, pavement structure, materials, and pavement distresses) were collected and the local calibration of the MEPDG was conducted in New Mexico. The MEPDG prediction model error was successfully reduced [8]. Climate data were extracted from the World Weather Online website, analysed, and converted to the MEPDG format to conduct the sensitivity analysis in Egypt [9]. To implement and use the MEPDG in Egypt, pavement distresses prediction models were developed for the non-freezing zone and design data was extracted from the LTPP database [10]. The material properties and specifications were determined from the Qatar Highway Design Manual (QHDM), climate data of Needles Airport in California were adapted, and the default traffic design inputs (Level 3) were used to conduct the sensitivity analysis in the State of Qatar [11]. In China, the local material properties was collected and default (Level 3) axle load distribution and climate data were used in local calibration of the thermal cracking model [12]. In Saudi Arabia, local design data such as traffic, climate, and material are prepared to be used for local calibration of the MEPDG [13]. The traffic data (e.g., vehicle classification, growth rate, and truck distribution factors) was collected and the sensitivity analysis for various climate condition was carried out in Lebanon [14]. The experience of other countries has shown that local data collection is a laborious effort and some of the local data should be analysed and converted to the AASHTOWare Pavement ME Software format. Turkey is one of the countries that is trying to leave the existing empirical pavement design guide (AASHTO 1993) to the adaptation of MEPDG. In this regard, some initial works have been performed by Turkish General Directorate of Highways [15]. In this study, local design data (e.g., climate, traffic, and materials) were collected for different state highways in Izmir region from various government agencies.

\section{OBJECTIVE}

The main objective of this study is to prepare local design data (obtaining, analysing, and converting) to be used as design inputs for local calibration of the MEPDG in Izmir. With the aiming of achieving the objective, the following activities are performed. 

a) Climate data were obtained, analysed and converted to the text file with ".hcd" extension.
b) Traffic data were obtained, analysed, and converted to a suitable format required by the MEPDG.
c) Bound and unbound material properties were determined.

\section{LOCAL DATA COLLECTION METHODOLOGY}

Different road sections were selected in Izmir to collect the local design data such as material properties, traffic characteristics, and climate data. The selected road segments are located in the North, North-South, West, West-East, and South that can cover the whole zone (Table $1)$.

Table 1 - Selected roadway segments

\begin{tabular}{|c|c|c|}
\hline Roadway section number & Number of lanes & Direction/Location \\
\hline D240 & 4 & North \\
\hline D550 & 4 & North-South \\
\hline D505 & 2 & West \\
\hline D300 & 4 & West-East \\
\hline D310 & 4 & South \\
\hline
\end{tabular}

\subsubsection{Climate Data}

It is well known that flexible pavement is significantly affected by environmental conditions. The asphalt concrete (AC) is affected by air temperature gradient while the unbound layers and subgrade are sensitive to moisture variation and freezing-thawing cycles [16], [17]. The MEPDG uses different climate data such as hourly temperature, hourly precipitation, hourly wind speed, hourly sun shine, and hourly humidity as design inputs to calculate the environmental effects on pavement performance using the Enhanced Integrated Climatic Model (EICM) software. The EICM is a powerful software that calculates the temperature and moisture effects on pavement structure. The USA and Canada's climate data are embedded in the Pavement ME Design Software, however the climate data is required to be collected for local conditions. In Turkey, the climate model has not yet been calibrated and the climate data files have not been created in EICM format [4], [5]. A five year period (20132018) climate data was taken from the Turkish State Meteorological Services, the data was analysed and various missing weather data were identified. The missing data (hours) were calculated using the average before and after the missing data points. The missing data (days, months, or years) were also adapted from the nearest weather stations. Seventeen weather stations were selected, which cover the entire Izmir state (Table 2). The climate data were converted to the text file with extension ".hed" based on Pavement ME Design Software format. Each climatic file consists of: date $(\mathrm{YYYY} / \mathrm{mm} / \mathrm{dd} / \mathrm{hr})$, air temperature $\left({ }^{\circ} \mathrm{C}\right)$, precipitation $(\mathrm{mm})$, wind speed $(\mathrm{m} / \mathrm{hr})$, sunshine $(\%)$, and humidity $(\%)$ (Figure 1$)$. 
Data collection for Implementation of the Mechanistic-Empirical Pavement Design ...

Table 2 - Selected weather stations

\begin{tabular}{|l|l|l|l|}
\hline Station number & Station name & Latitude & Longitude \\
\hline 17180 & Dikili & 39.0737 & 26.888 \\
\hline 17787 & Aliaga & 38.7922 & 26.9682 \\
\hline 17742 & Konak & 27.171 & 53.000 \\
\hline 17789 & Menemen & 38.6237 & 27.0433 \\
\hline 17219 & Izmir Adnan Menderes Airport & 38.295 & 27.1481 \\
\hline 17822 & Ödemis & 38.2157 & 27.9642 \\
\hline 17854 & Selcuk & 37.9423 & 27.3669 \\
\hline 18447 & Kiraz & 38.2192 & 28.2028 \\
\hline 18029 & Tire & 38.133 & 27.8165 \\
\hline 18443 & Buca & 38.375 & 27.1953 \\
\hline 18031 & Bornova & 38.4666 & 27.2166 \\
\hline 17218 & Cigli Airport & 38.5127 & 27.0144 \\
\hline 17749 & Kemalpaşa & 38.4639 & 27.3705 \\
\hline 17221 & Cesme & 38.3036 & 26.3724 \\
\hline 18028 & Urla & 38.3628 & 26.8322 \\
\hline 18444 & Güzelbahce & 38.3717 & 26.8908 \\
\hline 18032 & Karaburun & 38.6401 & 26.5081 \\
\hline
\end{tabular}

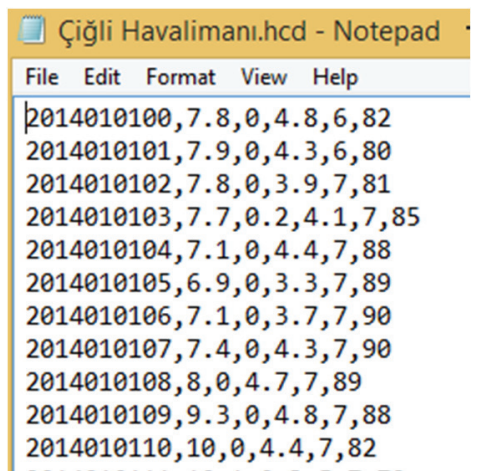

Figure 1 - An example of climate data in MEPDG required format

\subsubsection{Traffic Data}

The MEPDG requires extensive detailed traffic inputs which are categorized in four main parts [1], [18].

a) Base Year Traffic Information (Initial Two Way Annual Average Daily Truck Traffic (AADTT), Number of Lanes in Design Direction, Percent Trucks in Design Direction, Percent Trucks in Design Lane, Operational Speed). 
b) Traffic Volume Adjustment Factors (Monthly Adjustment Factors, Vehicle Class Distribution, Hourly Distribution, Traffic Growth Factors).

c) Axle Load Distribution Factors,

d) General Traffic Inputs (number of axles per truck, axle configuration, wheelbase, and lateral traffic wander).

In this study, traffic data were collected from the Turkish General Directorate of Highways published reports such as Traffic and Transportation Information [19] and Characteristics and Trends of Heavy Truck Traffic and Good Transportation [20].

\subsubsection{Vehicle Classification}

The MEPDG uses ten vehicle classes (4-13) in which Class 4 indicates buses and Class 5 through 13 indicate trucks and trailers. In the MEPDG, vehicles are classified based on truck types, axle numbers, and axle types (single, tandem, triple, and quad) [1], [18], while in Turkey, vehicles are classified based on vehicle types in five groups: 1) cars, 2) medium goods vehicles (MGV), 3) buses, 4) Trucks, and 5) Trailers [15]. This classification cannot be used in the MEPDG as design inputs. Therefore, comprehensive efforts have been made to develop a new truck classification to be used in the MEPDG. The observed trucks in Turkey were categorized in seven classes based on truck types, axle numbers and axle types (single, tandem, and tridem). Thus, first of all, Class 1 (cars) were removed from the proposed vehicle classification. Secondly, Class 2 (medium goods vehicles) with 3.5-10 tons weigh was merged into other classes since it consists of buses and trucks (30\% bus and $70 \%$ truck). The Class 3 (buses) was remained unchanged and it is equivalent to Class 4 in the MEPDG. The Class 4 (trucks) has been divided into three subclasses (5-7) based on axles numbers and axle types. The Class 5 representing the trailers, has been grouped into three subclasses (810). In the proposed truck classification: Class 1 is buses, Classes 2, 3, and 4 are single-unit trucks, and Class 5-7 indicate the single unit trailers. The vehicle classes 11, 12, and 13 have not been observed in Turkey (Table 3) [19], [20].

Table 3. Trucks classification

\begin{tabular}{|c|c|c|c|l|}
\hline MEPDG & \multirow{2}{*}{ Existing } & $\begin{array}{c}\text { Proposed } \\
\text { classification }\end{array}$ & $\begin{array}{l}\text { Axles } \\
\text { types/numbers }\end{array}$ & \multicolumn{1}{|c|}{ Description } \\
\hline 4 & Buses & 1 & $1.2,1.21,1.22$ & Buses \\
\hline \multirow{2nnnyy}{*}{5} & & 2 & $1.1,1.2$ & $\begin{array}{l}\text { Two-axle, six-tire, single } \\
\text { unit trucks }\end{array}$ \\
\cline { 4 - 5 } & \multirow{2}{*}{ Trucks } & 3 & $1.21,1.22$ & $\begin{array}{l}\text { Three-axle, single-unit } \\
\text { trucks }\end{array}$ \\
\cline { 4 - 5 } & & 4 & $\begin{array}{c}11.21,11.22,1.122, \\
1.122,1.211, \\
11.121,11.122\end{array}$ & $\begin{array}{l}\text { Four or more axle, single } \\
\text { unit trucks }\end{array}$ \\
\hline
\end{tabular}


Data collection for Implementation of the Mechanistic-Empirical Pavement Design ...

Table 3. Trucks classification (continue)

\begin{tabular}{|c|c|c|c|c|}
\hline MEPDG & Existing & $\begin{array}{c}\text { Proposed } \\
\text { classification }\end{array}$ & $\begin{array}{l}\text { Axles } \\
\text { types/numbers }\end{array}$ & Description \\
\hline 8 & \multirow{3}{*}{ Trailers } & 5 & $1.2+11,1.2+22$ & $\begin{array}{l}\text { Four axle, single trailer } \\
\text { trucks }\end{array}$ \\
\hline 9 & & 6 & $\begin{array}{l}1.21+22,1.22+11, \\
1.22+22,1.2+111, \\
1.2+122,1.2+222\end{array}$ & $\begin{array}{l}\text { Five axle, single trailer } \\
\text { trucks }\end{array}$ \\
\hline 10 & & 7 & $1.22+111,1.22+222$ & $\begin{array}{l}\text { Six or more axles, single } \\
\text { trailer trucks }\end{array}$ \\
\hline 11 & - & - & - & $\begin{array}{l}\text { Five axle, multi trailer } \\
\text { trucks }\end{array}$ \\
\hline 12 & - & - & - & $\begin{array}{l}\text { Six axle, multi trailer } \\
\text { trucks }\end{array}$ \\
\hline 13 & - & - & - & $\begin{array}{l}\text { Seven or more, multi } \\
\text { trailer trucks }\end{array}$ \\
\hline
\end{tabular}

\subsubsection{Average Annual Daily Truck Traffic (AADTT)}

The Turkish General Directorate of Highways uses hundreds of automatic vehicle counting devices to measure traffic volume and classify the vehicles. The average annual daily traffic (AADT) is available only for current vehicle classification (cars, MGV, buses, trucks, and trailers) which cannot be directly used for the proposed truck classification. Therefore, the truck distribution factors of proposed truck classification were extracted from [19], [20] (Table 4).

Table 4 - Truck distribution percentage for proposed truck classification

\begin{tabular}{|c|c|c|}
\hline $\begin{array}{c}\text { Current vehicle } \\
\text { classification }\end{array}$ & $\begin{array}{c}\text { Proposed truck } \\
\text { classification }\end{array}$ & $\begin{array}{c}\text { Truck distribution (TD) } \\
\%\end{array}$ \\
\hline Buses & 4 & 100 \\
\hline \multirow{3}{*}{ Trucks } & 5 & 18.56 \\
\cline { 2 - 3 } & 6 & 50.39 \\
\cline { 2 - 3 } & 7 & 30.96 \\
\hline \multirow{3}{*}{ Trailers } & 8 & 1.35 \\
\cline { 2 - 3 } & 9 & 98.36 \\
\cline { 2 - 3 } & 10 & 0.28 \\
\hline
\end{tabular}

The AADTT for the proposed vehicle classification was calculated using the following equation (Equation 1). 
$A A D T T_{p i}=A A D T T_{c i} \times \mathrm{TD}_{i}$

Where, $\operatorname{AADTT}_{p i}$ is the average annual daily truck traffic for class $i$ of proposed truck classification. AADDT ${ }_{c i}$ is the average annual daily truck traffic for class $i$ of current vehicle classification, and $\mathrm{TD}_{i}$ is the truck distribution percentage. As the Medium Goods Vehicles class includes 30\% buses and 70\% trucks, its AADT was added to Class 4 and 5 .

\subsubsection{Vehicle Class Distribution Factors (VCDF)}

The share percentage of trucks are indicated by vehicle class distribution factors (VCDF) which was calculated by (Equation 2).

$$
V C D F_{i}=\frac{A A D T T_{i}}{A A D T T} \times 100
$$

Where, $\mathrm{VCDF}_{i}$ is the vehicle class distribution factor for classi, $\mathrm{AADDT}_{i}$ is the average annual daily truck traffic for classi, and AADDT is the average annual daily truck traffic for classification.

At the end of calculation, the sum of VCDF must be equal to 100. As seen in (Figure 2), the vehicle distribution percentage of vehicle classes 5, 6, and 9 are high in state roads in Izmir.

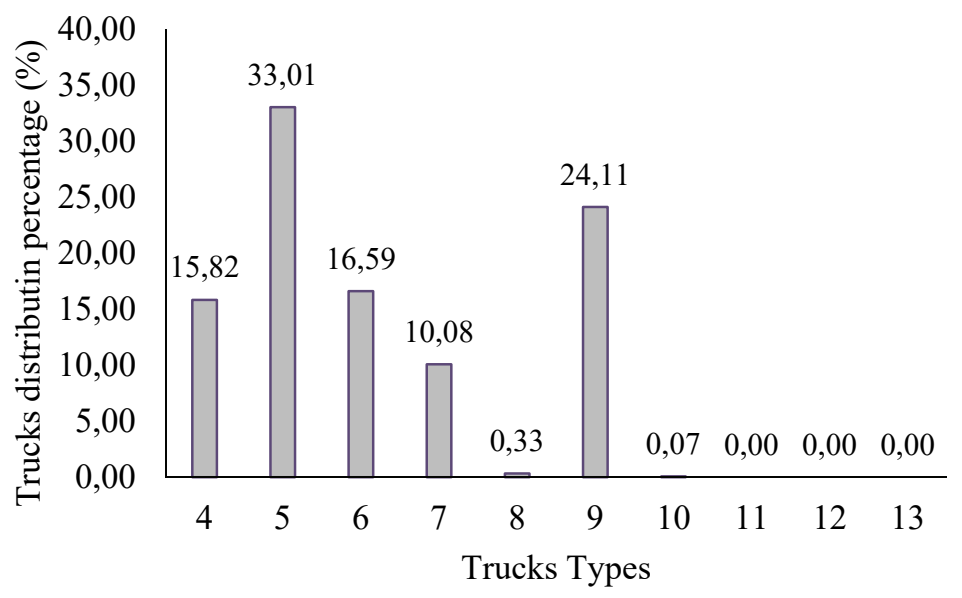

Figure 2 - Vehicle class distribution factors

\subsubsection{Vehicle Growth Rate}

Because the AADT is available for the current vehicle classification (cars, medium goods vehicles, trucks and trailers), a single growth rate was calculated for 5, 6, 7 and $8,9,10$ classes. As seen in (Table 5), the truck growth rate of classes 8, 9, and 10 are significantly high (13.37) that should be considered in pavement structural analysis and design in the future. 
Data collection for Implementation of the Mechanistic-Empirical Pavement Design ...

Table 5 - Vehicle class distribution factors and truck growth rates for state roads

\begin{tabular}{|c|c|c|c|}
\hline Vehicle class & Distribution (\%) & Growth rate (\%) & Growth function \\
\hline 4 & 15.82 & 1.76 & Linear \\
\hline 5 & 33.01 & 2.80 & Linear \\
\hline 6 & 16.59 & 2.80 & Linear \\
\hline 7 & 10.08 & 2.80 & Linear \\
\hline 8 & 0.33 & 13.37 & Linear \\
\hline 9 & 24.10 & 13.37 & Linear \\
\hline 10 & 0.07 & 13.37 & Linear \\
\hline 11 & 0.00 & 0 & - \\
\hline 12 & 0.00 & 0 & - \\
\hline 13 & 0.00 & 0 & - \\
\hline Total & 100 & & - \\
\hline
\end{tabular}

\subsubsection{Monthly Adjustment Factors}

The whole year traffic variation is indicated by traffic monthly adjustment factors (MAF). The monthly adjustment factors were calculated by (Equation 3). The sum of monthly adjustment factors should be equal to 12 . The monthly adjustment factors were presented in (Table 6) and (Figure 3) [21].

$$
M A F_{i}=\frac{A M D T T_{i}}{\sum_{i=1}^{12} A M D T T_{i}} \times 12
$$

Where, $\mathrm{MAF}_{i}$ is the vehicle monthly adjustment factor for classi, $\mathrm{AMDTT}_{i}$ is the average monthly daily truck traffic for classi.

Table 6 - Trucks monthly adjustment factors

\begin{tabular}{|l|c|c|c|c|c|c|c|c|c|c|}
\hline \multirow{2}{*}{ Month } & \multicolumn{10}{|c|}{ Trucks Classes } \\
\cline { 2 - 13 } & 4 & 5 & 6 & 7 & 8 & 9 & 10 & 11 & 12 & 13 \\
\hline Jan & 0.83 & 0.84 & 0.84 & 0.84 & 0.8 & 0.8 & 0.8 & 0 & 0 & 0 \\
\hline Feb & 0.79 & 0.8 & 0.8 & 0.8 & 0.77 & 0.77 & 0.77 & 0 & 0 & 0 \\
\hline Mar & 0.88 & 0.96 & 0.96 & 0.96 & 0.94 & 0.94 & 0.94 & 0 & 0 & 0 \\
\hline Apr & 0.9 & 0.99 & 0.99 & 0.99 & 0.96 & 0.96 & 0.96 & 0 & 0 & 0 \\
\hline May & 1.03 & 1.07 & 1.07 & 1.07 & 1.05 & 1.05 & 1.05 & 0 & 0 & 0 \\
\hline
\end{tabular}


Table 6 - Trucks monthly adjustment factors (continue)

\begin{tabular}{|l|c|c|c|c|c|c|c|c|c|c|}
\hline \multirow{2}{*}{ Month } & \multicolumn{10}{|c|}{ Trucks Classes } \\
\cline { 2 - 13 } & 4 & 5 & 6 & 7 & 8 & 9 & 10 & 11 & 12 & 13 \\
\hline Jun & 1.07 & 1.07 & 1.07 & 1.07 & 1.05 & 1.05 & 1.05 & 0 & 0 & 0 \\
\hline Jul & 1.25 & 1.1 & 1.1 & 1.1 & 1.13 & 1.13 & 1.13 & 0 & 0 & 0 \\
\hline Aug & 1.28 & 1.08 & 1.08 & 1.08 & 1.12 & 1.12 & 1.12 & 0 & 0 & 0 \\
\hline Sep & 1.05 & 1.03 & 1.03 & 1.03 & 1.07 & 1.07 & 1.07 & 0 & 0 & 0 \\
\hline Oct & 1.04 & 1.08 & 1.08 & 1.08 & 1.12 & 1.12 & 1.12 & 0 & 0 & 0 \\
\hline Nov & 0.92 & 0.99 & 0.99 & 0.99 & 1.04 & 1.04 & 1.04 & 0 & 0 & 0 \\
\hline Dec & 0.95 & 0.99 & 0.99 & 0.99 & 0.95 & 0.95 & 0.95 & 0 & 0 & 0 \\
\hline Total & 12 & 12 & 12 & 12 & 12 & 12 & 12 & 0 & 0 & 0 \\
\hline
\end{tabular}

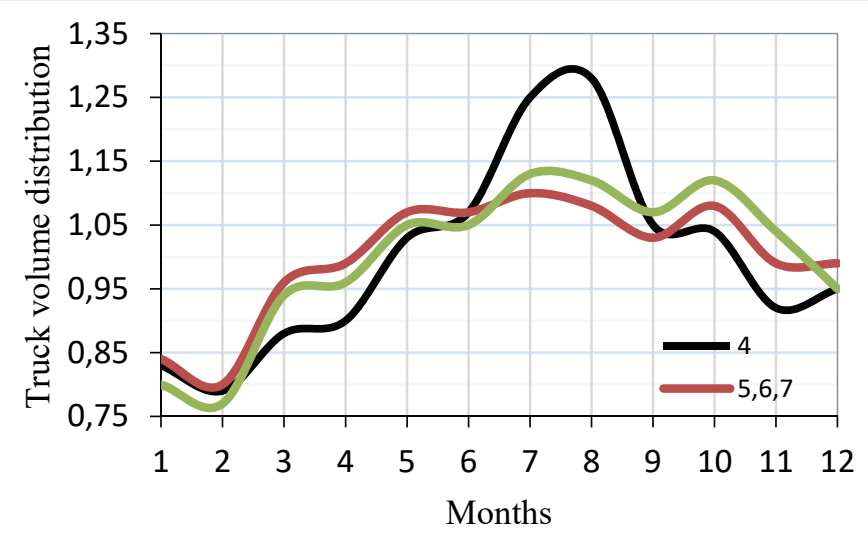

Figure 3 - Truck monthly adjustment factors

As seen (Figure 3), truck traffic volumes are decreased in the winter season and are then increased in the summer season.

\subsubsection{Truck Hourly Distribution Factors}

The truck hourly distribution factors represent the percentage of the total truck traffic within each hour of the day. The sum of 24-hourly distribution factors must be equal to 100 (Table 7) and (Figure 4). For state roads in Turkey, the truck hourly distribution percentage was extracted from Highway Traffic Flow Properties and Traffic Parameters [21]. 
Data collection for Implementation of the Mechanistic-Empirical Pavement Design ...

Table 7 - Truck hourly distribution factors

\begin{tabular}{|c|c|c|c|}
\hline Time period & Distribution (\%) & Time period & Distribution (\%) \\
\hline $00: 00-01: 00$ & 3.6 & $12: 00-13: 00$ & 5.0 \\
\hline $01: 00-02: 00$ & 3.0 & $13: 00-14: 00$ & 4.9 \\
\hline $02: 00-03: 00$ & 2.4 & $14: 00-15: 00$ & 5.0 \\
\hline $03: 00-04: 00$ & 2.2 & $15: 00-16: 00$ & 5.3 \\
\hline $04: 00-05: 00$ & 2.1 & $16: 00-17: 00$ & 5.4 \\
\hline $05: 00-06: 00$ & 2.4 & $17: 00-18: 00$ & 5.5 \\
\hline $06: 00-07: 00$ & 3.1 & $18: 00-19: 00$ & 5.3 \\
\hline $07: 00-08: 00$ & 3.9 & $19: 00-20: 00$ & 5.5 \\
\hline $08: 00-09: 00$ & 4.1 & $20: 00-21: 00$ & 4.8 \\
\hline $09: 00-10: 00$ & 4.4 & $21: 00-22: 00$ & 4.4 \\
\hline $10: 00-11: 00$ & 4.7 & $22: 00-23: 00$ & 4.1 \\
\hline $11: 00-12: 00$ & 5.0 & $23: 00-24: 00$ & 3.9 \\
\hline Total & 40.9 & Total & 59.1 \\
\hline
\end{tabular}

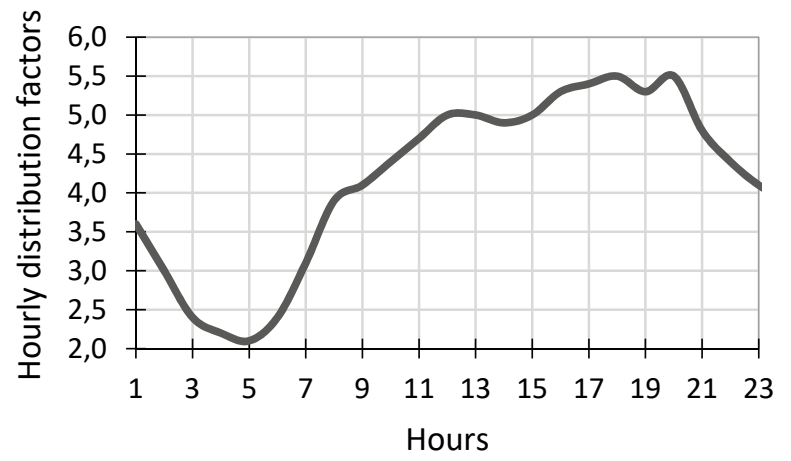

Figure 4 - Truck hourly distribution factors

As seen in (Figure 5) and (Table 7), the traffic volume is high during the day and reaches to the highest value at 18:00, the traffic volume decreases at 21:00 and reaches at the lowest level at 5:00.

\subsubsection{Axle Load Distribution Factors}

The Turkish General Directorate of Highways uses a weighbridge system placed at 350 stations to measure the axle loads associated with trucks. Consequently, they collect the 
distribution of axle loads at $1000 \mathrm{~kg}$ intervals unlike the MEPDG requesting axle load distribution at different intervals [20].

- $\quad$ Single axles from $1361 \mathrm{~kg}$ to $18597 \mathrm{~kg}$ in intervals of $454 \mathrm{~kg}$.

- $\quad$ Tandem axles from $2722 \mathrm{~kg}$ to $37197 \mathrm{~kg}$ in intervals of $907 \mathrm{~kg}$.

- $\quad$ Tridem axles from $5443 \mathrm{~kg}$ to $46266 \mathrm{~kg}$ in intervals of $1360 \mathrm{~kg}$.

The measured and collected axle loads in Turkey should be converted to the MEPDG required standard. The axle load distribution factors were obtained by the following three steps.

1. The measured axle load distribution (single, tandem, and tridem) was converted into the $454 \mathrm{~kg}, 907 \mathrm{~kg}$, and $1360 \mathrm{~kg}$ intervals. The difference between measured axle load distribution and converted axle load distribution are not significant (Figure 5), (Figure 6), and (Figure 7).

2. The collected axle load distributions are shared between all types of trucks (i.e., class 5 , $6,7,8,9$, and 10), therefore, at first, the share percentage of each truck was determined, and then the axle load distributions (single axle, tandem axle, and tridem axle) were calculated (Figure 8).

3. The axle load distribution factors were calculated by (Equation 4) [13].

$$
A L D F_{i j k}=\frac{{\text { No. of } \text { axles }_{i j k}}_{\text {Total No. of axles }}}{i j} \times 100
$$

Where $A L D F$ is the axle load distribution factor, $i$ is vehicle class from $4-10, j$ represents the month from 1-12, and $k$ is the load interval.

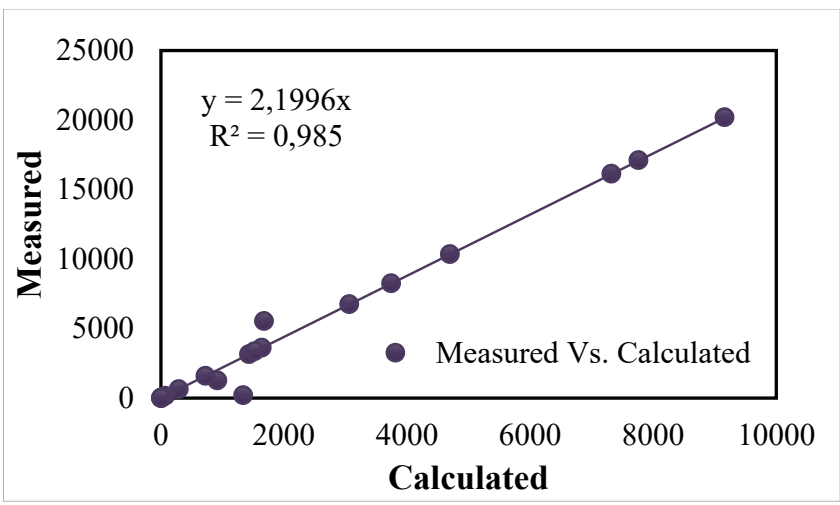

Figure 5 - Single axle load distribution (measured vs. calculated) 
Data collection for Implementation of the Mechanistic-Empirical Pavement Design ...

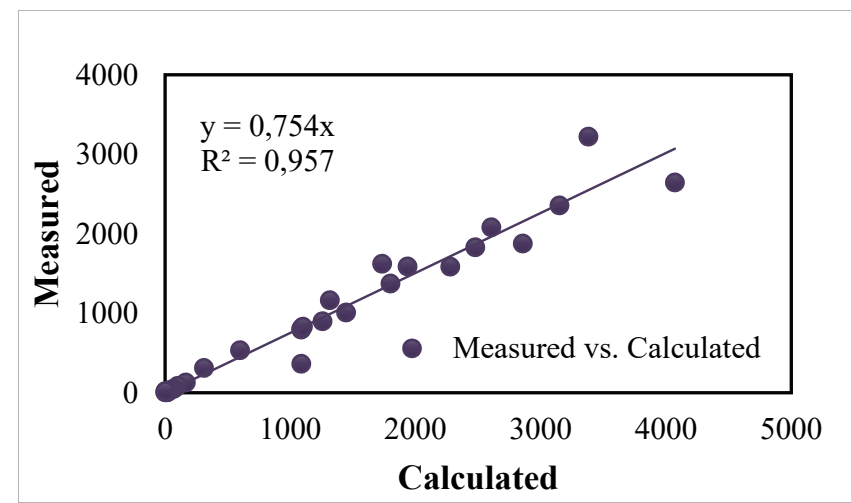

Figure 6 - Tridem axle load distribution (measured vs. calculated)

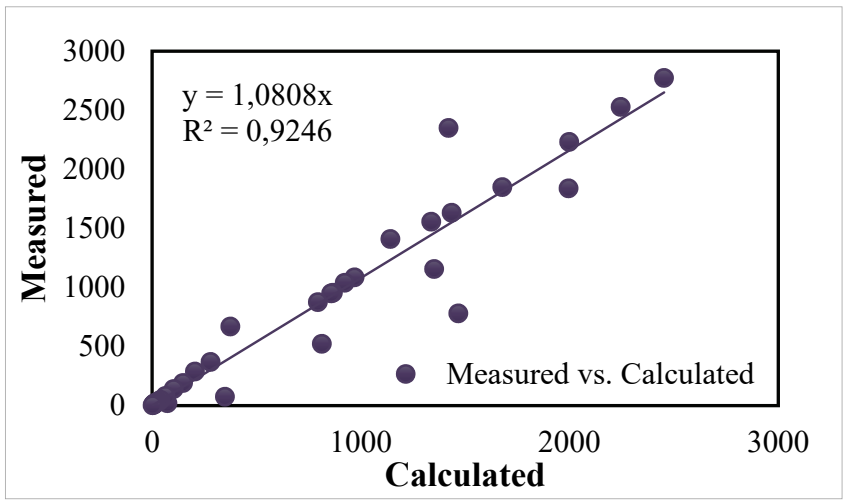

Figure 7 - Tandem axle load distribution (measured vs. converted)

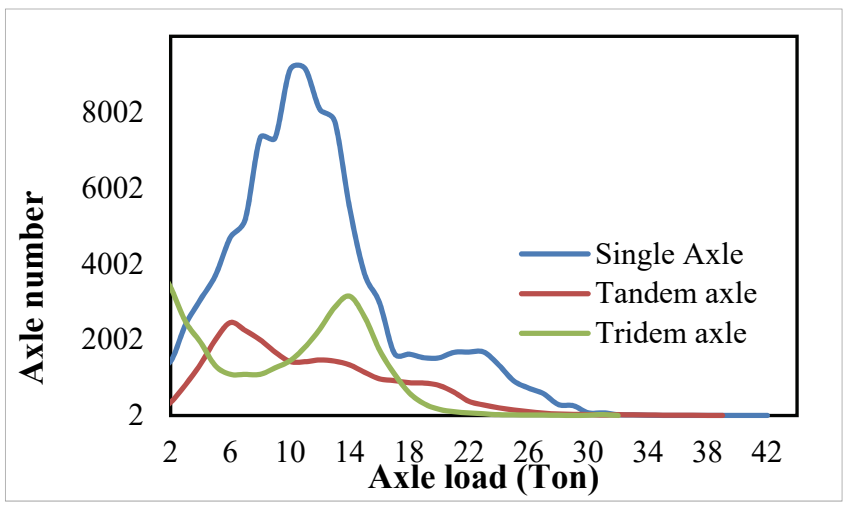

Figure 8 - Axle load distribution 
In Turkey, monthly axle load distribution is not available, so only one axle load distribution factors is obtained for all months (Figure 9). Besides, axle load regarding buses (Class 4) is not measured in Turkey, so the default axle load distribution factors were chosen [20].

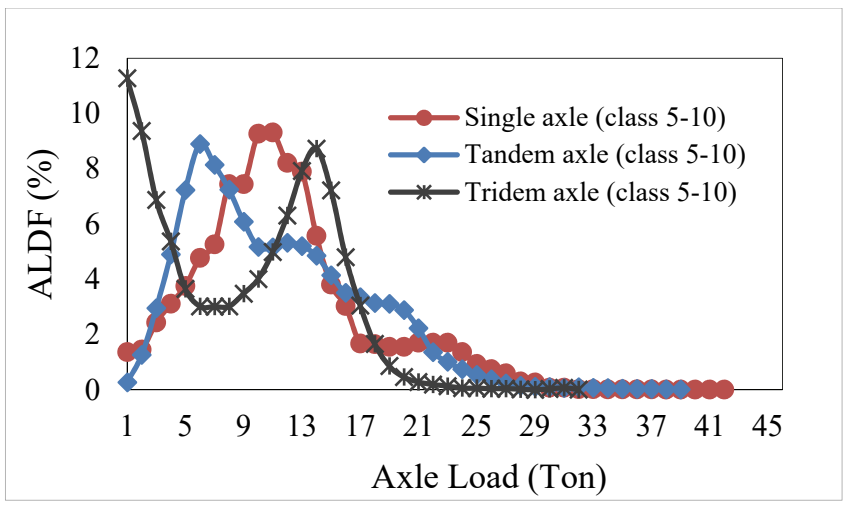

Figure 9 - Axle load distribution factors

\subsubsection{General Traffic Inputs}

The following local design inputs were collected for Izmir, Turkey.

\subsubsection{Lateral traffic wander}

- Mean wheel location, the distance between outer edge of the wheel and the edge marking for the pavement. The default value of $460 \mathrm{~mm}$ is used for Izmir region.

- $\quad$ Traffic wander standard deviation, the default value of $256 \mathrm{~mm}$ is used for Izmir region.

- Design lane width, the value of $3.5 \mathrm{~m}$ is used for Izmir region.

\subsubsection{Number of axles per truck}

The average number of axles for each truck class (Class 4 to 10) for each axle type (single, tandem, and tridem) is called the number of axles per truck. The number of axles per truck was calculated for state roads in Izmir (Table 8).

Table 8 - The average number of axles per truck

\begin{tabular}{|c|c|c|c|c|}
\hline Vehicle class & Single & Tandem & Tridem & Quad \\
\hline 4 & 1.96 & 0.04 & 0.00 & 0 \\
\hline 5 & 2.00 & 0.00 & 0.00 & 0 \\
\hline 6 & 1.00 & 1.00 & 0.00 & 0 \\
\hline 7 & 1.33 & 0.33 & 0.68 & 0 \\
\hline 8 & 2.00 & 1.00 & 0.00 & 0 \\
\hline
\end{tabular}


Data collection for Implementation of the Mechanistic-Empirical Pavement Design ...

Table 8 - The average number of axles per truck (continue)

\begin{tabular}{|c|c|c|c|c|}
\hline Vehicle class & Single & Tandem & Tridem & Quad \\
\hline 9 & 1.99 & 0.03 & 0.99 & 0 \\
\hline 10 & 1.00 & 1.00 & 1.00 & 0 \\
\hline 11 & 0 & 0 & 0 & 0 \\
\hline 12 & 0 & 0 & 0 & 0 \\
\hline 13 & 0 & 0 & 0 & 0 \\
\hline
\end{tabular}

\subsubsection{Axle configuration}

The axle configuration and axle spacing were presented in Table 9 and Table 10, respectively [22].

Table 9 - Truck Axle Configuration for Izmir

\begin{tabular}{|l|c|c|}
\hline Axle configuration & $\begin{array}{c}\text { Values } \\
\text { (MEPDG) }\end{array}$ & $\begin{array}{c}\text { Values } \\
\text { (Turkey) }\end{array}$ \\
\hline Average axle width $(\mathrm{m})$ & 2.59 & 2.45 \\
\hline Dual tire spacing $(\mathrm{mm})$ & 305 & 305 \\
\hline Tire pressure (psi) & 120 & 101 \\
\hline
\end{tabular}

Table 10 - Axle Spacing for Izmir

\begin{tabular}{|c|c|c|}
\hline Axle types & $\begin{array}{c}\text { Average axle spacing } \\
\text { (MEPDG), } \mathrm{m}\end{array}$ & $\begin{array}{c}\text { Average axle spacing } \\
\text { (Turkey), } \mathrm{m}\end{array}$ \\
\hline Tandem & 1.45 & 1.36 \\
\hline Tridem & 1.68 & 1.25 \\
\hline Quad & 1.32 & NA* \\
\hline
\end{tabular}

* Not applicable in Turkey

\subsubsection{Wheelbase}

The spacing between steering axle and first axle in a truck is named as wheel base and divided in three ranges of short, medium, and long. Typically Class 5 indicates short trucks; Class 6 and 7 indicate medium trucks and Class 8-13 indicate long trucks. Table 11 presents default values used in this study. 
Table 11 - Truck wheelbase

\begin{tabular}{|c|c|c|}
\hline $\begin{array}{c}\text { Axle } \\
\text { types }\end{array}$ & $\begin{array}{c}\text { Average axle spacing } \\
\text { between axle group, } \mathrm{m}\end{array}$ & $\begin{array}{c}\text { Percent of truck } \\
\%\end{array}$ \\
\hline Short & 3.66 & 33 \\
\hline Medium & 4.57 & 33 \\
\hline Long & 5.49 & 34 \\
\hline
\end{tabular}

\section{MATERIAL PROPERTIES}

The MEPDG requires various and detailed material properties in three hierarchical input levels. In Level 1, design inputs are obtained through the laboratory or site tests. In Level 2, design inputs were collected using the correlation with other material properties. In Level 3, embedded design inputs in the Pavement ME Design Software were used or obtained using empirical predictive equations [1]. In this study, comprehensive efforts have been carried out to collect Level 2 and Level 3 design inputs. Therefore, several documents such as Turkish Highway Technical Specification [23], Asphalt Mixture Laboratory Studies [24], and Turkish Flexible Pavement Design Guide [15] were carefully reviewed and local design data were obtained as explained in the following subtitles.

\section{1. Hot Mixed Asphalt Material Properties}

The asphalt binder properties, asphalt volumetric properties and aggregate gradation that is commonly used in wearing course and binder course in Izmir are presented in Table 12, 13 and 14 , respectively.

Table 12 - Binder inputs (Input Level 3)

\begin{tabular}{|l|c|}
\hline \multicolumn{1}{|c|}{ Inputs } & Values \\
\hline Penetration grade, $(0.1 \mathrm{~mm})$ & $50 / 70$ \\
\hline Performance graded, $(\mathrm{PG})$ & $64-16$ and $64-22$ \\
\hline
\end{tabular}

Table 13 - Volumetric inputs (Input Level 3)

\begin{tabular}{|l|c|c|c|}
\hline \multicolumn{1}{|c|}{ Inputs } & $\begin{array}{c}\text { Wearing } \\
\text { course }\end{array}$ & $\begin{array}{c}\text { Binder course } \\
\text { (Type 1) }\end{array}$ & $\begin{array}{c}\text { Binder course } \\
\text { (Type 2) }\end{array}$ \\
\hline Maximum specific gravity, $\left(\mathrm{kN} / \mathrm{m}^{3}\right)$ & 25 & 25 & 25 \\
\hline Bulk specific gravity, $\left(\mathrm{kN} / \mathrm{m}^{3}\right)$ & 24 & 24 & 24 \\
\hline Effective binder content by volume $V_{b e}(\%)$ & 8 & 8 & 8 \\
\hline Air voids $V_{a}(\%)$ & $4-5$ & $4-6$ & $4-6$ \\
\hline Voids in mineral aggregates $V M A(\%)$ & $14-16$ & $13-15$ & $12-14.5$ \\
\hline Voids filled with asphalt $V F A(\%)$ & $65-75$ & $60-75$ & $55-75$ \\
\hline
\end{tabular}


Data collection for Implementation of the Mechanistic-Empirical Pavement Design ...

Table 14 - Aggregate gradation (Input Level 3)

\begin{tabular}{|l|c|c|c|}
\hline \multicolumn{1}{|c|}{ Inputs } & Wearing course & $\begin{array}{c}\text { Binder course } \\
\text { (Type 1) }\end{array}$ & $\begin{array}{c}\text { Binder course } \\
\text { (Type 2) }\end{array}$ \\
\hline \% Passing the No.200 sieve & $3-8$ & $2-7$ & $0-8$ \\
\hline Cumulative \% retained on in No.4 sieve & $58-28$ & $70-48$ & $70-38$ \\
\hline Cumulative \% retained on in 3/8" sieve & $28-0$ & $52-30$ & $57-25$ \\
\hline Cumulative \% retained on in 3/4" sieve & 0 & $20-0$ & $40-10$ \\
\hline
\end{tabular}

Inputs Level 3 were selected based on other design inputs such as poison's ratio, surface shortwave absorptivity, coefficient of thermal contraction of the mix, reference temperature, thermal conductivity, heat capacity of asphalt, asphalt indirect tensile strength, and asphalt creep compliance.

\section{2. Unbound and Subgrade Material Properties}

The MEPDG requires the Resilient Modulus $\left(\mathrm{M}_{\mathrm{R}}\right)$ of subgrade and base materials. The $\mathrm{M}_{R}$ can be obtained through laboratory tests or predicted via empirical predictive equations. In Turkey, the resilient modulus of subgrade and unbound materials were determined through an empirical equation (Equation 5) [25].

$$
M_{R}=1750\left(D_{B S K}+K\right)^{0.438} \times C B R^{0.4}\left(\frac{1}{1+\log (N o .200)}\right)^{0.35(L L \times P I+1)^{0.06}} \times\left(\frac{\gamma_{\max }{ }^{2}}{N o .4}\right)^{0.09 \log \left(\omega_{o p t}\right)}
$$

Where;

$\mathrm{M}_{\mathrm{R}} \quad=$ resilient modulus

$\mathrm{D}_{\mathrm{BSK}}=$ HMA layer total thickness

$\mathrm{CBR}=$ California bearing ratio $(\%)$

$\omega=$ moisture content

$\gamma \quad=$ maximum dry density

LL = liquid limit

PI = plasticity index

No.200 $=\%$ passing the No. 200 sieve

No.4 $=\%$ passing the No.4 sieve

$\mathrm{K}=$ depth correction factor $(\mathrm{k}=0$ for base and subbase, $\mathrm{k}=17$ for subgrade)

It seems that (Equation 6) significantly underestimates the resilient modulus of unbound materials comparing to the equation suggested by MEPDG in (Table 15) and (Figure 10). 
In this study, the equation suggested by MEPDG was used to predict the resilient modulus for base and subbase instead of Equation 5. The CBR values for base layer and subbase layer was taken as $100 \%$ and $50 \%$, respectively, based on the information found in the Turkish Technical Specification for Highways and Turkish Flexible Pavement Design Guide.

Table 15 - Comparison between MEPDG and local predictive equations

\begin{tabular}{|c|c|c|c|c|c|c|c|c|c|c|}
\hline CBR (\%) & 10 & 20 & 30 & 40 & 50 & 60 & 70 & 80 & 90 & 100 \\
\hline $\mathrm{M}_{\mathrm{R}}(\mathrm{ksi})$ by Equation 5 & 11.2 & 17.4 & 22.5 & 27.1 & 31.2 & 35.1 & 38.8 & 42.2 & 45.5 & 48.7 \\
\hline $\mathrm{M}_{\mathrm{R}}(\mathrm{ksi})$ by Equation 6 & 9.2 & 12.1 & 14.2 & 15.9 & 17.4 & 18.7 & 19.9 & 21.0 & 22.0 & 23.0 \\
\hline
\end{tabular}

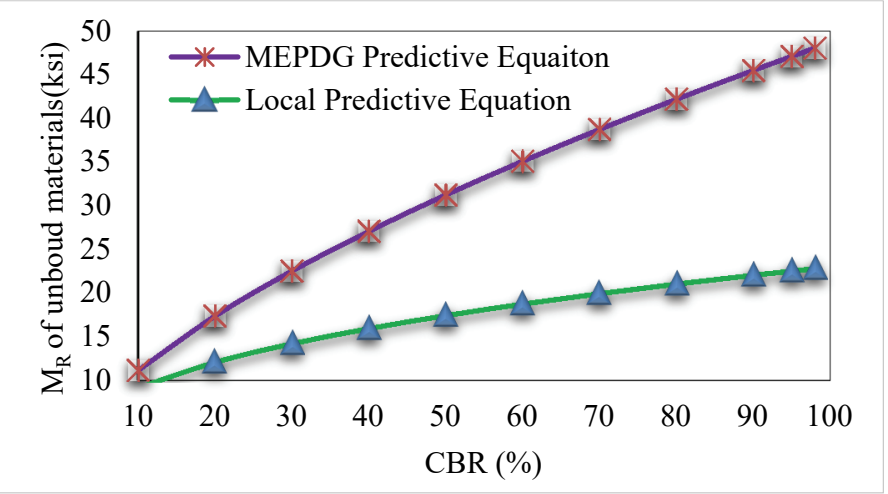

Figure 11 - Comparison between MEPDG and local predictive equations

\section{CONCLUSIONS}

In this study, climate data, traffic characteristics and material properties have been obtained from various local sources to be used for local implementation of the MEPDG in Izmir. The collected local data were analysed and some of the data were found to be deficient for direct use as a design input. Therefore, the data was converted to the MEPDG required format which is summarized in the following paragraphs:

- The obtained climate data were analysed, and various missing weather data were observed. The missing data were completed by using the average of data before and after the missing points. The values were adapted from other closest weather stations. Finally, climate data were converted to the text file with extension ".hcd".

- In Turkey, vehicles are classified based on their types into five groups which significantly differ from the MEPDG truck classification standard. Therefore, vehicles were classified in 10 classes according to the vehicle type, axle number, and axle spacing. 
- The truck distribution indicates that vehicles in class 5 and 9 have the highest share percentage while trucks in classes 9 and 10 have little distribution.

- The growth rate of trucks in classes 8,9 and 10 are very high.

- In Turkey, only the axle loads of the heavy trucks $(5,6,7,8,9$, and 10) are measured using weighbridge method at the interval of $1000 \mathrm{~kg}$ regarding all axle types (single, tandem, and tridem). The quad axle load has not been measured. In this study, the axle load distributions were calculated at the intervals of default axle load distribution factors, which were used for class 4 , and quad axle load distribution factors were set to zero.

- The local resilient modulus predictive equation significantly underestimates the resilient modulus in comparison with the equation suggested by MEPDG. In this study the equation suggested by MEPDG is used.

\section{Acknowledgment}

The authors would like to express their profound gratitude to the Department of Scientific and Research Project, Dokuz Eylul University, Izmir, Turkey for their financial support (Project Number: 2019.KB.FEN.038). They also thank and appreciate the Graduate School of Natural and Applied Sciences, Dokuz Eylul University for their valuable supports.

\section{References}

[1] AASHTO, Mechanistic empirical pavement design guide. American Association of State Highway and Transportation Officials, Washington, D.C., USA, 2008.

[2] Timm, D. H., Roobin, M. M., Tran N., Rodezno C., Flexible pavement design - State of the practice, NCAT Report 14-04, National Asphalt Pavement Association, USA, 2014.

[3] AASHTO, Guide for the local calibration of the mechanistic-empirical pavement design guide. Washington, D.C: American Association of State Highway and Transportation Officials (AASHTO), Washington, D.C., USA, 2010.

[4] Öztürk, H. I., Tan, E. B., Şengün, E., Yaman, İ. Ö., Farklı trafik, zemin, malzeme ve iklim koşulları için mekanistik-ampirik (M-E) yöntemle tasarlanan derzli donatısız rijit üstyapı sistemlerinin karşılaştırılması, J. Fac. Eng. Archit. Gazi Univ., 34(2), 771-783, 2019.

[5] E. Şengün, E. H. I. Öztürk, H. I. and İ. Ö. Yaman, İ. Ö., Mekanistik-Ampirik ve Geleneksel Beton Yol Tasarım Yöntemlerinin Karşılaştırılması: Afyon-Emirdağ Deneme Kesimi, Tek. Dergi, 31 (5), 2020.

[6] Caliendo, C., Local calibration and implementation of the mechanistic-empirical pavement design guide for flexible pavement design, J. Transp. Eng., 138(3), 348-360, 2012. 
[7] Ghosh, A., Padmarekha, A., Krishnan, J. M., Implementation and proof-checking of mechanistic-empirical pavement design for Indian highways using AASHTOWARE Pavement ME Design Software, Procedia - Soc. Behav. Sci., 104, 119-128, 2013.

[8] Tarefder, R., Rodriguez-Ruiz, J. I., Local calibration of MEPDG for flexible pavements in New Mexico, J. Transp. Eng., 139(10), 981-991, 2013.

[9] Elshaeb, M. A., El-Badawy, S. M., Shawaly, E. S. A., Development and impact of the Egyptian climatic conditions on flexible pavement performance, Am. J. Civ. Eng. Archit., 2(3), 115-121, 2014.

[10] M. Dadwan, M. Abo-Hashema, H. Faheem, and M. Hashem, "Modeling Pavement Performance Using LTPP Database for Flexible Pavements,” Tek. Dergi, 31(4), 2020.

[11] Sadek, H. A., Masad, E. A., Sirin, O., Al-Khalid, H., Sadeq, M. A., Little, D., Implementation of mechanistic-empirical pavement analysis in the state of Qatar, Int. J. Pavement Eng., 15(6), 495-511, 2014.

[12] Ma, H., Wang, D., Zhou, C., Feng, D., Calibration on MEPDG low temperature cracking model and recommendation on asphalt pavement structures in seasonal frozen region of China, Adv. Mater. Sci. Eng., Vol. 2015, 1-11, 2015.

[13] Alqaili, A. H., Alsoliman H. A., Preparing data for calibration of mechanistic-empirical pavement design guide in central Saudi Arabia, World Acad. Sci. Eng. Technol. Int. J. Urban Civ. Eng., 11(2), 248-255, 2017.

[14] Chhade, R. H., Mrad, R., Houssami, L., Chehab, G., Asce, A. M. Formulation of traffic inputs required for the implementation of the M-E PDG formulation of traffic inputs required for the implementation of the M-E PDG in data-scarce regions : Lebanon case study, J. Mater. Civ. Eng. ASCE, 30(9), 04018198-14, 2018.

[15] Turkish General Directorate of Highways, Karayolları esnek üstyapılar projelendirme rehberi. Ankara, Turkey, 2008.

[16] Huang, Y. H., Pavement Analysis and Design, Second Edi. Pearson/Prentice Hall, USA, 2004.

[17] Schwartz, C. W., Carvalho, R. L., Evaluation of Mechanistic-Empirical Design Procedure, SP0077B41, University of Maryland, Maryland State, USA, 2007.

[18] AASHTO, Mechanistic-empirical pavement design. American Association of State Highway and Transportation Officials, Washington, D.C., USA, 2015.

[19] Turkish General Directorate of Highways, Trafik ve ulaşım bilgileri, Trafik Güvenliği Dairesi Başkanlığı Ulaşım Etütleri Şubesi Müdürlüğü, Ankara, Turkey, 2018.

[20] Turkish General Directorate of Highways, Karayollarında ağır taşıt trafiğinin ve yük taşımacılığının özellikleri ve eğilimleri, Trafik Güvenliği Dairesi Başkanlığı Ulaşım Etütleri Şubesi Müdürlüğü, Ankara, 2016.

[21] Turkish General Directorate of Highways, Devlet yolları trafik akımı özellikleri ve trafik parametreleri, Strateji Geliştirme Daire Başkanlığı Ulaşım ve Maliyet Etütleri Şubesi Müdürlüğü, Ankara, Turkey, 2009. 
Data collection for Implementation of the Mechanistic-Empirical Pavement Design ...

[22] Özcana, S., Akpinar, M. V., Esnek Üstyapılarda Kritik Tekerlek ve Aks Konfigürasyonların Mekanistik Analizlere Göre Tespit Edilmesi, Teknik Dergi, 25(121), 6625-6654, 2014.

[23] Turkish General Directorate of Highways, Karayolu teknik şartname, Vol. 1. Turkish General Directorate of Highways, Ankara, Turkey, 2013.

[24] Orhan, F., Bitümlü karışımlar lab. çalışmaları, Karayolları Genel Müdürlüğü, Ar-Ge Dairesi Başkanlığı Üstyapı Geliştirme Şubesi Müdürlüğü, Ankara, 2012.

[25] Güngör, A. G., Sağlık, A., Mekanistik ampirik üstyapı tasarımında esneklik modülünün şartnamelere uyarlanmas1, 5th Eurasphalt \& Eurobitume, 455-463, 2012. 